\title{
High-Speed Railways and the Environmental Sustainability: Realising the Potential
}

\author{
Labib Azzouz* and Anson Jack \\ The University of Birmingham, United Kingdom
}

Submission: March 26, 2020; Published: April 03, 2020

*Corresponding author: Labib Azzouz, PhD Researcher at the University of Birmingham, Birmingham Centre for Railway Research and Education Gisbert Kapp, The University of Birmingham,Birmingham, B15 2TT, United Kingdom

Keywords: Energy consumption; Carbon emissions; Environmental; Climate ambitions

\section{Introduction}

The efficiency of railways in terms of energy consumption and carbon emissions is remarkable when compared with other transportation modes [1]. When compared with cars and flights, high-speed railways (HSR) offer an environmentally competitive alternative [2]. HSR can significantly reduce $\mathrm{CO}_{2}$ emissions that are related to transport activities, specifically by replacing cars and short- to medium-haul flights [3]. The competitiveness of HSR is featured in trips with distances under $700 \mathrm{~km}$, and between densely populated cities [1].

This paper aims to shed light on the environmental advantage of HSR, especially when compared with cars and airplanes. To reach this aim, the paper offers a benchmarking exercise that compares the $\mathrm{CO}_{2}$ emissions of HSR, airplanes, and cars along four selected corridors.

\section{HSR and $\mathrm{CO}_{2}$ emissions}

HSR projects generate $\mathrm{CO}_{2}$ emissions at all stages of the lifecycle of the project. These stages include the planning, construction, operation, maintenance, and recycling [3]. The construction stage is considered a major contributor, especially in cases where the project requires an immense number of tunnels, bridges, and earthwork activities [4]. Still, the operation stage might be the biggest contributor to the overall emissions among all stages. For instance, the operation of the Beijing-Shanghai HSR line constitutes around 70 per cent of the total lifecycle emissions, followed by the construction and maintenance stages, with 20 and 9 per cent respectively [4]. Emissions of the operation stage comprise those emitted while producing electricity for traction, heating, on-board services plus electricity used for operating stations and other buildings that are linked to railway activities $[3,5]$.
In the operation stage, the per passenger.km $\mathrm{CO}_{2}$ emissions of HSR can be very low, especially when compared with flights and cars. Leboeuf [3] discuss that for a 600-km trip, $\mathrm{CO}_{2}$ emissions of HSR can be almost 90 per cent lower than those of aviation.

\section{Methodology}

To facilitate the benchmarking exercise, the study selected four famous corridors. These constitute some of the most successful HSR corridors around the world, and they connect major economic regions in their countries. Data for the benchmarking exercise were obtained and calculated from different sources including annual and sustainability reports of HSR operators, publications of the International Union of Railways (UIC), and journal articles. These sources use different indicators for reporting on the $\mathrm{CO}_{2}$ emissions. So, to facilitate a valid comparison, different indicators were standardised. For instance, the Central Japan Railway Company disclosed information about the per seat.km emissions [6], which was converted into the per passenger.km emissions. The Eco Passenger Carbon Tool provides emission values of the Madrid-Seville and Paris-Lyon corridors at occupancy rates of 85 per cent, from which emission values at other occupancy rates were calculated. Emissions of the Beijing-Shanghai corridor were calculated based on annual emissions, occupancy rates, and daily passenger numbers offered by Lin et al. [4]. Finally, capacities and specifications of the HSR locomotives that run along the four corridors were provided by UIC [7].

\section{Results and Analysis}

Figure 1 shows two comparisons; benchmarking emissions of HSR along specific corridor against emissions along other corridors; and, benchmarking HSR against cars and flights. 


\section{International Journal of Environmental Sciences \& Natural Resources}

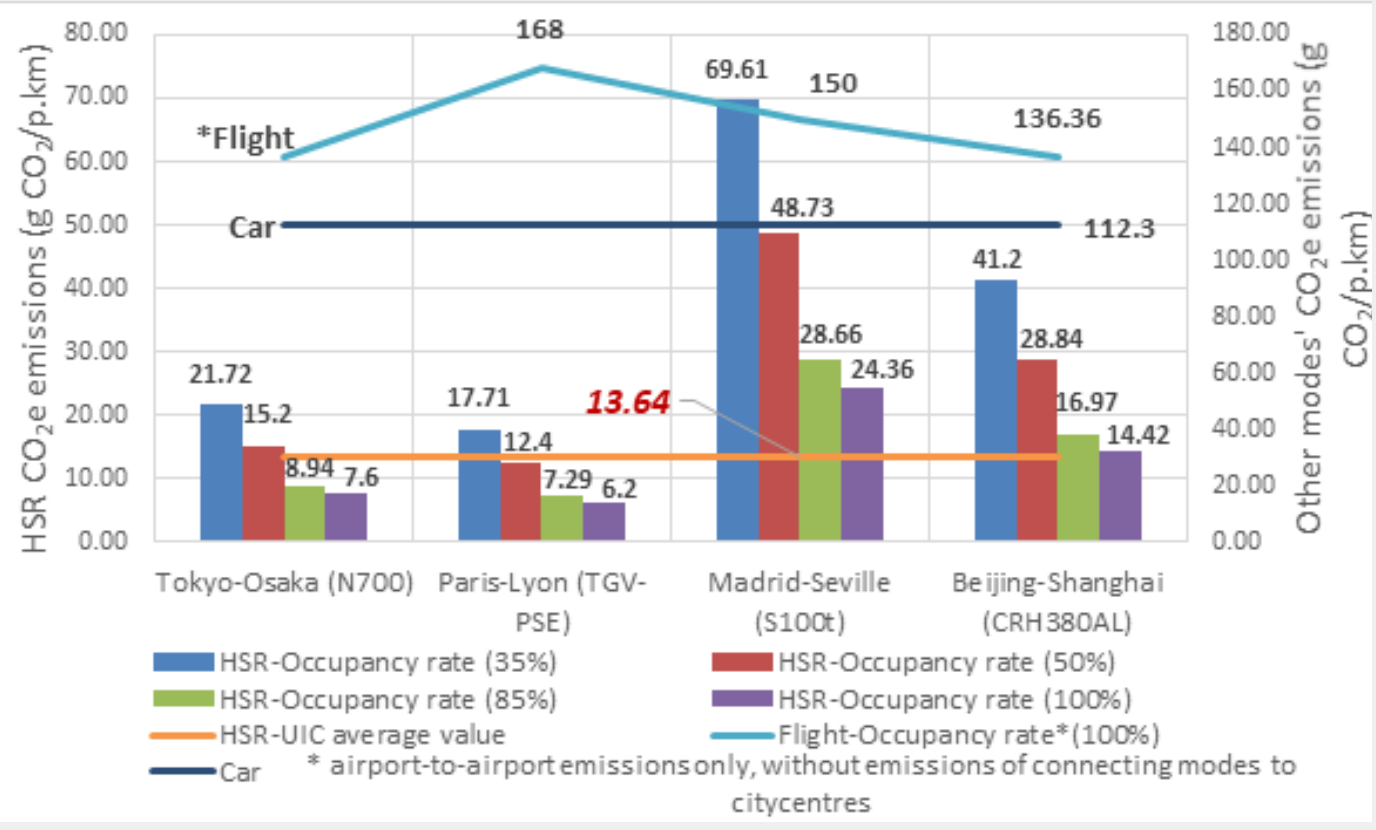

Figure 1: Carbon footprint comparison of different transport modes along selected corridors. Source: author's elaboration on [3,4,6-10].

Regarding the first comparison, Figure 1 shows significant variations between emissions associated with different occupancy rates along different corridors. The HSR services along the French corridor showed the best performance at all occupancy rates, followed by HSR services along the Tokyo-Osaka route, whereas HSR service along the Spanish corridor accounted for the highest emissions. HSR services of the Beijing-Shanghai corridor shower a mediocre performance. At an occupancy rate of 85 per cent, the TGV of the Paris-Lyon line generated as little as $7.3 \mathrm{~g} \mathrm{CO}_{2} \mathrm{e} / \mathrm{p} . \mathrm{km}$, compared to almost 9, 17, and 28.7g CO 2 e/p.km on Tokyo-Osaka, Beijing-Shanghai, and Madrid-Seville lines respectively. When locomotives were fully loaded with passengers, emissions of the Madrid-Seville line were around four times higher than their counterparts of the Paris-Lyon corridor.

The variation among countries in terms of the per passenger. $\mathrm{km} \mathrm{CO}$ emissions can be explained by differences in the energy mix used in each country. The lowest $\mathrm{CO}_{2}$ emissions of HSR in France is related to the fact that France depends heavily on nuclear power for generating electricity. So, the decarbonization of the energy mix is an essential driver for reducing $\mathrm{CO}_{2}$ emission, and using fossil fuels such as coal, oil, and gas emits much higher emissions when compared with nuclear and renewable energies [11]. Considering the second comparison, HSR showed a superior performance at all occupancy rates. Even at the lowest occupancy rates, emissions of HSR services were much lower than those of cars and flights, along all chosen corridors. For instance, when only 35 per cent of the train was full, an HSR journey between Beijing and Shanghai generated around $41 \mathrm{~g} \mathrm{CO}_{2} \mathrm{e} / \mathrm{p} . \mathrm{km}$, while similar trips by airplanes and cars emitted almost 136 and $112 \mathrm{~g} \mathrm{CO}_{2} \mathrm{e} / \mathrm{p}$. $\mathrm{km}$ respectively. Also, a flight between Paris and Lyon generated almost $168 \mathrm{~g} \mathrm{CO}_{2} \mathrm{e} / \mathrm{p} . \mathrm{km}$, around 10 times the emissions of a similar HSR trip, at an occupancy rate of 35 per cent. When the train was full - the occupancy rate was 100 per cent - flying between Paris and Lyon generated around 168g CO $\mathrm{g}_{2} \mathrm{e} / \mathrm{p} . \mathrm{km}$; almost 27 times the emissions emitted by HSR. Similarly, emissions associated with travelling by car between Paris and Lyon was higher than those of HSR by around 18 times.

\section{Conclusion}

This paper sheds light on the environmental advantage of HSR. The benchmarking exercise revealed that HSR along chosen corridors and at different occupancy rates had superior environmental performance and the per passenger.km $\mathrm{CO}_{2}$ emissions of HSR were significantly lower than emissions of cars and flights. In some cases, the per passenger.km $\mathrm{CO}_{2}$ emissions of HSR were almost 27 and 18 times lower than emissions of flights and cars respectively. Another finding is that HSR in France emitted the least amount of emissions when compared with the HSR of other countries. This is explained by the fact that France depends heavily on nuclear power for generating electricity. Using an energy mix that comprises renewable and clean energies could notably reduce $\mathrm{CO}_{2}$ emissions. To conclude, HSR offer an environmentally sustainable mode that can be a key part of the plan to meeting climate ambitions globally. 


\section{References}

1. Papadopoulou S (2017) High-speed rail presents major opportunities for decarbonisation of transport. Online: Modern Diplomacy.

2. IEA (2017) High-speed rail presents major opportunities for decarbonisation of transport. Paris: The International Energy Agency.

3. Leboeuf M (2018) High-speed rail-Fast track to sustainable mobility Paris: International Union of Railways.

4. Lin J, Li H, Huang W, Xu W, Cheng S (2019) A Carbon Footprint of HighSpeed Railways in China: A Case Study of the Beijing-Shanghai Line. Journal of Industrial Ecology 23(4): 869-878.

5. Bergendorff M, Mathiot-Bobin C, Petersen FB, Halder M, Kuppelwieser H (2008) UIC leaflet No. 330 Railway specific environmental performance indicators. Paris: International Union of Railways.
6. JR-Central (2018) Annual report 2018. Nagoya: Central Japan Railway Company.

7. UIC (2019) World High Speed Rolling Stock.

8. CFC (2019) Flight carbon footprint calculator. Basingstoke: Carbon Footprint Ltd.

9. Ecopassenger (2019) Compare the energy consumption, the $\mathrm{CO}_{2}$ emissions and other environmental impacts for planes, cars and trains in passenger transport [Online]. Paris: UIC Sustainable Development Unit.

10.Hüttermann R, Knörr W (2016) EcoPassenger-Environmental Methodology and Data Update 2016. Hannover: Institute for Energy and Environmental Research.

11. UIC-AND-IEA (2017) Railway Handbook. Paris: International Energy Agency \& International Union of Railways.

Your next submission with Juniper Publishers will reach you the below assets

- Quality Editorial service

- Swift Peer Review

- Reprints availability

- E-prints Service

- Manuscript Podcast for convenient understanding

- Global attainment for your research

- Manuscript accessibility in different formats

( Pdf, E-pub, Full Text, Audio)

- Unceasing customer service

Track the below URL for one-step submission https://juniperpublishers.com/online-submission.php 